\title{
PEMBINAAN, PELAKSANAAN DAN KESAN MODUL TATABAHASA BAHASA TAMIL BERPANDUKAN TEORI INTERAKSIONAL, TEORI KONSTRUKTIVISME DAN STRATEGI DEKONSTRUKTIVISME DALAM KALANGAN PELAJAR TINGKATAN EMPAT
}

\author{
Rathidevi SHANMUGAMA ${ }^{1}$ \\ Chew Fong PENG*2 \\ Mohanadass RAMASAMY 3 \\ ${ }^{1}$ Institut Pengajian Termaju, Universiti Malaya, 50603 Kuala Lumpur \\ ${ }^{2}$ Fakulti Pendidikan, Universiti Malaya, 50603 Kuala Lumpur. \\ ${ }^{3}$ Fakulti Sastera dan Sains Sosial, Universiti Malaya \\ ${ }^{1}$ rathidevishanmugam@yahoo.com \\ fpchew@um.edu.my* \\ 3rmohana_dass@um.edu.my
}

Manuscript received 16 September 2020

Manuscript accepted 31 May 2021

*Corresponding author

https://doi.org/10.33736/ils.2580.2021

\begin{abstract}
ABSTRAK
Dalam pembelajaran bahasa Tamil, para pelajar sering menghadapi masalah untuk menguasai kata kerja dalam pembelajaran tatabahasa bahasa Tamil dengan baik. Penggunaan modul tatabahasa dengan Strategi Dekonstruktivisme sebagai bahan bantu mengajar dalam pengajaran akan membantu pengajaran dan pembelajaran kata kerja bahasa Tamil. Justeru kajian ini dijalankan untuk membina modul pengajaran tatabahasa Bahasa Tamil dengan meninjau pendapat 10 orang panel pakar, dan seterusnya menganalisis pencapaian pelajar sebelum dan selepas penggunaan modul
\end{abstract}


dalam pengajaran dan pembelajaran tatabahasa kata kerja bahasa Tamil. Teori Konstruktivisme dan Teori Interaksionalisme diaplikasikan dalam pembinaan modul tatabahasa kata kerja bahasa Tamil. Dalam kajian ini, 70 orang pelajar Tingkatan 4 dipilih sebagai kumpulan eksperimen dan pencapaian pelajar diukur sebelum dan selepas menggunakan modul dalam pengajaran dan pembelajaran kata kerja bahasa Tamil. Dapatan kajian menunjukkan bahawa pengajaran dan pembelajaran kata kerja bahasa Tamil yang menggunakan modul dapat meningkatkan pencapaian pelajar secara signifikan.

Keywords: bahasa Tamil; kata kerja; modul; pengajaran dan pembelajaran; tatabahasa

\title{
DEVELOPING, IMPLEMENTATION AND EFFECTS OF TAMIL GRAMMAR MODULE BASED ON THEORY OF INTERACTIONAL, THEORY OF CONSTRUCTIVISM AND DECONSTRUCTIVISM STRATEGY AMONG FORM FOUR STUDENTS
}

\begin{abstract}
In learning Tamil language, students often face difficulties in mastering the verbs in learning the Tamil grammar properly. The use of Deconstructivism Strategy module as a teaching aid will help the teaching and learning of Tamil verbs. Therefore, the aim of this study was to develop a Tamil grammar teaching module by reviewing the opinions of 10 expert panelists, and analysed students' achievements before and after the use of the module in teaching and learning the Tamil verbs. Constructionism Theory and Interactionalism Theory were applied in the construction of Tamil verb grammar modules. In the study, the achievement of 70 Form 4 students who were selected as the experimental group was measured before and after using the module. The findings of the study showed that the teaching and learning of Tamil verbs by using the grammar module significantly improved students' achievements.
\end{abstract}

Keywords: Tamil language; verbs; module; teaching and learning; grammar 


\section{Pengenalan}

Bahasa Tamil telah diiktiraf sebagai salah satu mata pelajaran yang diserapkan ke dalam sistem pendidikan formal di Malaysia hampir di setiap peringkat. Menurut Kartheges (2017), mata pelajaran bahasa Tamil telah diserapkan secara rasmi sebagai mata pelajaran elektif pada tahun 1962. Para pelajar lepasan sekolah rendah Tamil mengambil subjek ini sebagai subjek elektif di peringkat Penilaian Tingkatan 3 (PT3) dan Sijil Pelajaran Malaysia (SPM). Bahasa Tamil dipelajari oleh para pelajar menengah rendah, iaitu dari tingkatan peralihan, tingkatan satu, dua dan tiga dan menengah atas, iaitu tingkatan empat dan lima. Tatabahasa merupakan tulang belakang kepada sesuatu bahasa (Annamala, Omar, \& Veeralakshmi, 2017). Pendidikan Bahasa Tamil sekolah menengah menekankan penggunaan tatabahasa mengikut kemampuan pelajar-pelajar (Muthukumar, 2020). Untuk mencapai tujuan tersebut, guru-guru perlu merancang dan memilih aspek tatabahasa yang akan diajar berserta contoh penggunaannya dalam pelbagai konteks dan kegiatan bahasa yang bermakna sama ada di dalam atau di luar bilik darjah.

Sehubungan dengan itu, kata kerja memainkan peranan yang penting dalam pembelajaran tatabahasa di sekolah menengah. Ini adalah kerana kata kerja akan disoal dalam Kertas 2 Bahasa Tamil dalam peperiksaan SPM. Soalan-soalan kertas SPM mempunyai dua bahagian, iaitu bahagian objektif dan bahagian subjektif. Pemahaman pelajar-pelajar sangat penting dalam penguasaan tatabahasa kata kerja. Selain itu, kata kerja yang akan menghubungkan sesuatu perkataan menjadi sebuah ayat. Justeru, penggunaan kata kerja yang tepat akan membantu para pelajar dalam membina ayat yang betul dan gramatis. Dapat disimpukan bahawa pemahaman dan penggunaan kata kerja yang mendalam mampu memberi kesan dalam tatabahasa dan juga penulisan.

Aplikasi strategi secara eksplisit juga boleh membantu mereka menguasai aspek ini secara mendalam. Terdapat beberapa langkah untuk menggunakan strategi ini dalam pengajaran dan pembelajaran. Langkah-langkah tersebut lebih menjurus kepada percambahan konsep-konsep yang melibatkan 10 kata kerja yang termaktub dalam tujuh langkah pengenalan. Setiap langkah tersebut mempunyai kelebihan dan kepentingan tersendiri. Para pelajar berupaya menghayati saripati kata kerja tatabahasa bahasa Tamil apabila setiap langkah diperhalusi dengan baik bersama bahan bantu pengajaran yang sesuai. Strategi dekonstruktivisme dapat membantu para pelajar dalam peningkatan penguasaan terhadap kata kerja. Justeru, pengkaji dalam kajian ini cuba merungkai permasalahan yang dihadapi oleh para pelajar dan pihak guru. Selain itu, pengkaji akan membangunkan satu pendekatan baharu dalam pengajaran bahasa Tamil, iaitu pengajaran kata kerja tatabahasa bahasa Tamil berbantukan modul yang dibangunkan berasaskan strategi struktur dekonstruktivisme.

Oleh itu, objektif kajian ini adalah untuk:

1. reka bentuk modul kata kerja tatabahasa bahasa Tamil berasaskan Dokumen Standard Kurikulum dan Pentaksiran (DSKP Semakan) bagi pelajar tingkatan empat; dan 
2. membangunkan modul kata kerja tatabahasa bahasa Tamil berasaskan pendekatan struktur dekonstruktivisme bagi pelajar tingkatan empat.

\section{Sorotan Kajian}

Pendidikan di Malaysia sudah memanfaatkan pengajaran dan pembelajaran menggunakan modul (Ali, Abdullah, \& Ab. Rahman, 2019). Bidang pendidikan di Malaysia telah lama memanfaatkan pengajaran dan pembelajaran yang menggunakan modul kerana ia meraih pelbagai kebaikan yang dibuktikan daripada kajian Ali dan Mahamod (2016) dan Lai (2017), bahasa Inggeris pula dijalankan oleh Masnan et al. (2018) dan Javed et al. (2015), manakala bagi bahasa Arab, kajian dijalankan oleh Yahya et al. (2016), Zulkifli et al. (2018) dan Ali et al. (2019). Maka, pengembangan pengetahuan dalam bentuk pedagogi baharu yang dihasilkan dalam bentuk modul dapat membantu para guru dalam pengajaran yang lebih efisien (Ali \& Mahamod, 2016). Penggunaan modul agak terhad dalam pengajaran bahasa Tamil di sekolah menengah kebangsaan. Jeyadevi (2020) telah menyatakan modul bagi pengajaran dan pembelajaran bahasa Tamil sangat kurang dihasilkan dan penghasilannya lebih menjurus kepada pengajaran seperti aktiviti dan latihan. Modul yang digunakan itu adalah untuk memudahkan pengajaran secara keseluruhan oleh guru semata-mata dan tidak mengambil kira pembelajaran pelajar dan pengkhususan setiap topik atau subtopik tidak diberi perhatian.

Kajian-kajian berkaitan masalah dan minat mempelajari bahasa Tamil telah dijalankan oleh Selvajothi (2017) dan Nadeson (2011) tentang perkembangan bahasa Tamil. Namun begitu, tidak ada kajian yang berkaitan dengan pembangunan modul tatabahasa bahasa Tamil yang berasaskan strategi dekonstruktivisme untuk meningkatkan kemahiran tatabahasa dalam kalangan murid. Oleh yang demikian, kajian tentang pembangunan modul pengaplikasian strategi struktur dekonstruktivisme dalam pengajaran dan pembelajaran tatabahasa Tamil perlu dijalankan. Kata kerja merupakan komponen yang penting dalam pembelajaran bahasa Tamil. Jadi, pembinaan modul tatabahasa kata kerja menjadi sesuatu yang penting bagi memastikan tatabahasa bahasa Tamil dikuasai sepenuhnya oleh pelajar-pelajar tingkatan empat.

Sehingga kini, kajian modul tatabahasa dalam bahasa Arab dan bahasa Melayu telah banyak dibangunkan. Dalam pada itu, Yahya et al. (2016) berusaha mereka bentuk suatu modul pembelajaran asas bahasa Arab khusus untuk pelajar warga emas. Reka bentuk modul itu dibina berdasarkan langkah-langkah reka bentuk instruksi yang terdiri daripada lima fasa utama, iaitu analisis, reka bentuk, pembangunan, pelaksanaan dan penilaian modul berasaskan teori dan prinsip pembelajaran dewasa Knowles. Kajian ini menekankan bahawa pemilihan kosa kata yang tepat dan bersesuaian dengan psikologi warga emas akan membantu pemerolehan bahasa dalam kalangan mereka.

Kajian Ali dan Mahamod (2016) melaporkan proses pembangunan dan penilaian kebolehgunaan modul terhadap kemahiran bahasa Melayu kanak-kanak prasekolah. Semasa proses pembangunan, modul itu disemak oleh lapan orang pakar bidang yang 
berbeza. Beberapa cadangan dikenal pasti dan penambahbaikan dibuat berdasarkan cadangan yang diberikan. Modul yang dimurnikan kemudian dinilai ketepatan kandungannya oleh 20 orang penilai, terdiri daripada lapan orang pakar bidang yang sama dan 12 orang guru prasekolah. Proses pelaksanaan dan penilaian modul dilakukan di dua bilik darjah bagi menguji kebolehgunaan modul. Enam murid daripada dua prasekolah Kementerian Pendidikan Malaysia dipilih bagi tujuan pengumpulan data. Data kualitatif diambil melalui pemerhatian rakaman video. Kaedah pengumpulan data dibuat menggunakan rekod anekdot dan sampel kerja murid. Dapatan menunjukkan interaksi dengan bahan permainan dan rakan semasa bermain telah membantu kanak-kanak menguasai kemahiran bahasa Melayu secara emergent tanpa bimbingan guru sepenuhnya.

Kajian selanjutnya oleh Lai (2017) adalah mengenai penulisan bahasa Melayu dan telah membangunkan modul penulisan bahasa Melayu bagi pelajar tingkatan empat. Hasil dapatan penilaian modul telah memberi impak yang mendalam dan pelajar-pelajar di mana mereka telah menyatakan pengajaran guru berbantukan modul adalah efektif dan berbeza dengan guru yang lain. Selain itu, dapatan kajian juga membuktikan bahawa pelajar-pelajar gemar menggunakan contoh karangan yang disediakan dalam modul.

Rusdi et al. (2018) menjelaskan tentang Modul HEBAT Bacaan sebagai satu strategi pengajaran dan pembelajaran membaca dalam usaha meningkatkan literasi bacaan pelajar sekolah menengah dari tingkatan satu hingga tingkatan empat. Modul ini mempunyai nilai tambah dalam pengajaran dan pembelajaran membaca Bahasa Melayu kerana pendekatan yang digunakan adalah menyeluruh mencakupi aspek strategik pengajaran dan pembelajaran, cadangan aktiviti, bahan rangsangan/simulasi dan projek penilaian pembelajaran.

Selain itu, kajian Zulkifli et al. (2018) memfokuskan kepada Pusat Bahasa Arab Selangor (PBAS) dengan meninjau kekuatan modul pengajaran dan pembelajaran bahasa Arab yang interaktif. Kajian itu dijalankan dengan menggabungkan dua kaedah, iaitu temu bual pegawai PBAS dan soal selidik terhadap peserta yang mengikuti kursus di PBAS. Dapatan kajian mendapati bahawa PBAS merupakan pusat bahasa Arab yang mempunyai kekuatan modul pengajaran dan pembelajaran interaktif berdasarkan kemampuan kelengkapan makmal Information and Communications Technology (ICT) dan kekuatan modul program pembelajaran interaktif. Selain itu, PBAS juga didokongi tenaga-tenaga pengajar dari dalam dan luar negara. Hasil dapatan soal selidik juga menunjukkan para peserta berpuas hati dengan modul yang disediakan oleh PBAS.

Di samping itu, kajian Hussin dan Marosadee (2019) dijalankan untuk membina sebuah modul yang berkesan bagi mengatasi masalah miskonsepsi dalam pembelajaran 'adad dan ma'dūd. Kajian terdahulu menunjukkan pelajar sering terdedah kepada miskonsepsi dalam menguasai 'adad dan ma'dūd Arab. Hal ini kerana sistem pembahagian, konsep dan jenis 'adad serta ma'dūd dalam tatabahasa Arab yang berbeza dengan konsep yang diguna pakai dalam bahasa asal pelajar. Pendekatan Analysis, Design, Development, Implementation, and Evaluation (ADDIE) didapati sangat 
membantu dalam membina sebuah modul pembelajaran. Melalui fasa-fasa yang dicadangkan, maka modul ini dibina dengan membahagikan 'adad kepada tiga kelompok sahaja berdasarkan persamaan ciri-ciri dalam setiap kelompok berkenaan, iaitu 'adad sama, 'adad berlawanan dan 'adad neutral. Pembahagian ini dilakukan untuk mengurangkan masalah kekeliruan dalam kalangan golongan sasaran seterusnya menangani permasalahan miskonsepsi yang diketengahkan. Melalui pendekatan ini, diharap masalah miskonsepsi berkaitan tajuk ini dapat diatasi.

\section{Teori Kajian}

Modul ini dibina berdasarkan Teori Interaksional dan Teori Konstruktivisme selain strategi Dekonstruktisme. Teori Interaksional dipelopori Halliday (1973, 1975, 1978). Perkembangan teori ini berlaku sekitar tahun enam puluhan dan tujuh puluhan. Kebolehan kognitif sahaja tidak boleh menjelaskan penguasaan bahasa seseorang kanak-kanak itu (Aljoundi, 2014). Teori ini membolehkan pertukaran peranan yang berterusan antara penutur dan pendengar (guru dan pelajar), maka tatabahasa berfungsi sebagai pembentukan hubungan manusia.

Bagi memahami proses pemerolehan bahasa bagi setiap manusia, Halliday dan Hasan (1985) menyatakan bahawa kanak-kanak menjadi sumber bagaimana mereka terlibat dalam proses "bahasa pembelajaran" dan "belajar melalui bahasa" adalah penting untuk mengetahui proses pengalaman yang menjadi pengetahuan. Dalam teori interaksional, proses pemerolehan melibatkan proses mental dan interaksional (Thornberry \& Krohn, 2019). Teori ini lebih memberi penekanan dalam membina keyakinan berkomunikasi idea atau makna.

Dalam pengajaran bahasa, latihan-latihan membolehkan pelajar-pelajar menggunakan sistem bahasa yang betul. Aktiviti-aktiviti bahasa yang bermakna membolehkan pelajar-pelajar menggunakan struktur bahasa yang dipelajari dengan cara yang berkesan. Penerangan mereka menunjukkan bahawa aktiviti-aktiviti dalam modul strategi struktur dekonstruktivisme akan membantu pelajar-pelajar memahami kata kerja dengan lebih mendalam dan proses pemerolehan bahasa melalui teori instuksionalisme ini dapat mengukuhkan pemahaman kata kerja tatabahasa bahasa Tamil dalam kalangan pelajar-pelajar tingkatan empat.

Teori konstruktivisme pula dipelopori ahli psikologi, Lev Vygotsky (1896-1934) dan ahli psikologi Jean Piaget (1896-1980). Teori ini menunjukkan bahawa manusia membina pengetahuan dan makna dari pengalaman mereka. Menurut Vygotsky (1978), tumpuan kepada pembelajaran berpusatkan pelajar mungkin merupakan sumbangan yang paling penting dari teori konstruktivisme dan melalui konstruktivisme, para pelajar belajar dengan memasukkan maklumat baharu bersama-sama dengan apa yang sudah diketahui. Konstruktivisme adalah teori pembelajaran yang menerangkan bagaimana seseorang mungkin memperoleh pengetahuan dan belajar. Oleh itu, ia mempunyai aplikasi langsung untuk pendidikan. Teori ini menunjukkan bahawa manusia membina pengetahuan dan makna dari pengalaman mereka (Vygotsky, 1978). 
Menurut Vygotsky (1978), Zone of Proximal Development (ZPD) merupakan jarak antara actual development dan potential development. Menurut Vygotsky (1978) ZPD merupakan jarak antara tahap pembangunan sebenar yang ditentukan oleh penyelesaian masalah bebas dan tahap pembangunan yang berpotensi ditentukan melalui penyelesaian masalah di bawah bimbingan orang dewasa atau dengan kerjasama rakan sebaya yang lebih berkemampuan. Justeru kajian ini akan memberi penekanan kepada ZPD dan scaffolding di mana Teori konstruktivisme sosial akan diaplikasikan.

Seterusnya, strategi Dekonstruktivisme diperkenalkan oleh Derrida (1930-2014). Dalam Acts of Literature, beliau menyatakan bahawa dekonstruktivisme berpegang kepada konsep pemaknaan teks atau perkataan akan berbeza mengikut pemahaman dan sudut pandangan pembaca. Strategi ini tidak menuruti corak pembacaan dan pemahaman teks yang sedia wujud. Pembaca diberi kebebasan untuk menyelami maksud teks. Gough dan Price (2004) menyatakan bahawa dekonstruktivisme berorientasikan ke arah membuka, mengembangkan, menguatkan dan mengukuhkan makna pembacaan teks. Secara ringkasnya, dekonstruktivisme membantu pembaca mendampingi teks sebagai satu pemainan bahasa, di mana perkataan dalam suatu ayat ditanggalkan satu persatu atau teks dibenarkan diubah kedudukan tersendiri untuk membawa maksud atau maklumat tersendiri. Sebagai contohnya, aktiviti-aktiviti dalam modul strategi struktur dekonstruktivisme akan menyediakan berbagai-bagai maklumat tentang kata kerja tatabahasa bahasa Tamil yang melibatkan vinai mutru (kata kerja transitif), vinai etcham (kata keterangan), eaval (kata perintah), viyangol (kata seruan) dan eathirmarai (kata keterangan negatif) dengan memandu pelajar-pelajar tingkatan empat untuk memahami konsep dan menyelesaikan tugasan yang disediakan. Pelajarpelajar juga boleh berbincang sesama kawan-kawan sewaktu menjawab dan menulis jawapan aktiviti-aktiviti tersebut. Ini bermakna pelajar-pelajar yang lebih cerdas membantu kawan-kawan yang lain sewaktu berbincang dan menjawab aktiviti modul itu. Pada masa yang sama, scaffolding boleh berlaku semasa guru membantu pelajarpelajar untuk mengenali strategi terbaru dalam mempelajari kata kerja tatabahasa bahasa Tamil dalam bahagian vinai mutru, vinai etcham, eaval, viyangol dan eathirmarai.

\section{Metodologi}

Kajian ini menggunakan kaedah kuantitatif dengan menggunakan teknik Fuzzy Delphi. Sehubungan dengan itu, Lai (2017) menyatakan teknik Fuzzy Delphi sangat sesuai untuk menunjukkan nilai strata keutamaan dalam memilih konteks terpenting dan menentukan strata keperluan utama dalam melaksanakan kaedah atau elemen yang sesuai dalam pendidikan. Selain itu, teknik Fuzzy Delphi ini bukan sesuatu yang baharu, tetapi ia adalah satu instrumen yang telah dilakukan penambahbaikan terhadap kaedah Delphi. Instrumen mengumpul data terdiri daripada soal selidik, penilaian praujian dan 
pascaujian. Kajian ini melibatkan dua fasa, iaitu pembangunan modul dan penilaian modul.

Dalam fasa pertama, soal selidik "Pembangunan dan penilaian modul karangan Bahasa Melayu bagi murid Tingkatan Empat" yang dimodifikasi daripada Lai (2017) digunakan sebagai instrument kajian ini. Proses pengubahsuaian telah dilakukan mengikut kesesuaian konteks kajian. Soal selidik kajian ini (35 item) terbahagi kepada lima bahagian, iaitu strategi pengajaran dan pembelajaran tatabahasa kata kerja ( 6 item), Kaedah dan teknik pengajaran dan pembelajaran tatabahasa kata kerja (5 item), aktiviti pengajaran dan pembelajaran tatabahasa kata kerja (14 item), latihan pengajaran dan pembelajaran tatabahasa kata kerja bagi pelajar tingkatan empat (4 item), dan alat bantu mengajar yang sesuai digunakan (6 item).

Seramai 10 orang pakar bidang bahasa Tamil dipilih untuk dibuat tinjauan tentang empat aspek pembinaan modul tatabahasa. Kriteria utama dalam pemilihan panel pakar adalah mereka yang mempunyai kepakaran dalam bidang yang dikaji. Soal selidik diberikan kepada 10 panel pakar yang tersenarai di Jadual 1. Panel pakar terdiri daripada seorang professor dan tiga orang pensyarah kanan di universiti awam, tiga orang pensyarah di Institut Pendidikan Guru dan tiga orang guru cemerlang di sekolah menengah kebangsaan. Kesemua mereka mengkhusus dalam bidang bahasa Tamil, Linguistik, Tatabahasa dan Sastera Tamil. Tujuannya adalah untuk mendapatkan maklum balas mereka melalui keputusan Fuzzy Delphi untuk membina modul kata kerja bahasa Tamil Tingkatan 4. Panel pakar diminta untuk menyatakan persetujuan mereka bagi setiap item dengan menggunakan skala fuzzy 7 mata, iaitu 1 untuk teramat tidak setuju, 2 untuk sangat tidak setuju, 3 untuk tidak setuju, 4 untuk sederhana setuju, 5 untuk setuju, 6 untuk sangat setuju dan 7 untuk teramat setuju.

Jadual 1

Ahli Panel Pakar

\begin{tabular}{llll}
\hline Bidang Kepakaran & Tempat Bekerja & Taraf & Jumlah \\
\hline Pengajian India Bahasa Tamil & Universiti & Profesor & 1 orang \\
Linguistik Bahasa Tamil & Universiti & Pensyarah kanan & 3 orang \\
Pedagogi, Tatabahasa, Sastera & IPG & Pensyarah & 3 orang \\
Tatabahasa dan sastera & Sekolah Menengah & Guru Cemerlang & 3 orang \\
& Kebangsaan & & \\
\hline
\end{tabular}

Teknik Fuzzy Delphi menggunakan rumus fuzzy bagi mendapatkan nilai konsensus untuk mereka bentuk modul tatabahasa. Modul tatabahasa yang dibangunkan telah melalui pemurniaan sebelum memasuki fasa kedua, iaitu penilaian kesan pelaksanaan modul itu. Penilaian sumatif dalam bentuk praujian dan pascaujian terhadap 70 orang pelajar tingkatan empat sebelum dan selepas pengajaran modul tatabahasa diimplementasikan. Matlamat utama ini adalah untuk mengetahui tahap pencapaian pelajar mengenai tatabahasa bahasa Tamil. Kajian ini menggunakan reka 
bentuk sistem pengajaran Instructional System Design (ISD). Kent dan Branch (2002) berpendapat bahawa tujuan utama diadakan modul pengajaran adalah untuk mengesyorkan kaedah pengajaran berkesan yang boleh mengubah pengetahuan pelajar, kemahiran dan kemampuan pelajar. Ini jelas menunjukkan betapa pentingnya modul pengajaran kepada guru atau pembangun bahan pengajaran kerana aktiviti pengajaran yang terlibat adalah bersifat profesional.

Untuk tujuan penilaian, modul strategi struktur dekonstruktivisme tatabahasa kata kerja bahasa Tamil kepada 70 orang pelajar tingkatan empat dari dua buah sekolah. Kedua-dua sekolah terletak di daerah Skudai, Johor Bahru. Sekolah A mempunyai 38 orang pelajar dan sekolah B sebanyak 32 orang pelajar yang mengambil Bahasa Tamil dalam peperiksaan SPM. Sekolah-sekolah lain mempunyai bilangan pelajar yang rendah yang mengambil Bahasa Tamil. Jika ada pelajar yang ramai, guru berkenaan tidak dapat memberikan komitmen kepada pengkaji kerana kekangan waktu mengajar. Ini adalah kerana jumlah waktu mengajar dalam seminggu sebanyak 90 minit adalah sekadar mencukupi untuk guru-guru mengajar mengikut sukatan pelajaran yang ditetapkan. Pengkaji juga tidak memilih banyak sekolah kerana pegawai Bahasa Tamil di Jabatan Pendidikan Negeri meminta menghabiskan pengajaran modul sebelum peperiksaan akhir tahun bermula. Maka, pengkaji memilih untuk mengajar di dua buah sekolah tersebut kepada pelajar seramai 70 orang sahaja.

Seterusnya, penilaian sumatif, iaitu praujian dan pascaujian dijalankan terhadap 70 orang pelajar tersebut. Kertas penilaian sumatif dijalankan pengesahan daripada tiga orang orang guru cemerlang pada 14 Mei 2019, supaya soalan-soalan tersebut sesuai dan tepat. Kejelasan bahasa bersesuaian dengan pengetahuan sedia ada pelajar, kerelevenan soalan dengan bidang yang dikaji dan ketepatan soalan mengikut DSKP Semakan 2018.

Pengkaji mengadakan praujian untuk mengenali tahap penguasaan tatabahasa kata kerja dalam kalangan 38 orang pelajar tingkatan empat di Sekolah A pada tarikh 2 Julai 2019. Selepas itu, dari pukul 2.30 hingga 3.30 petang hari selasa setiap minggu, pengkaji mengimplementasikan enam modul kepada pelajar-pelajar tingkatan empat di Sekolah A selama 12 minggu. Pada waktu cuti sekolah, pengajaran modul itu terpaksa ditangguhkan ke minggu hadapan. Pada minggu terakhir, pengkaji mengadakan pascaujian pada 27 Ogos 2019 untuk menguji kesan pelaksanaan modul dan tahap pencapaian pelajar dalam tatabahasa kata kerja.

Berdasarkan cadangan 308 orang pelajar tingkatan empat melalui soal selidik, lapan orang guru bahasa Tamil tingkatan empat, kesepakatan dan persetujuan 10 orang panel pakar melalui teknik Fuzzy Delphi, pengkaji berjaya membangunkan modul strategi struktur dekonstruktivisme tatabahasa kata kerja bahasa Tamil untuk pelajar tingkatan empat.

Bagi Sekolah B, pengkaji memulakan dengan praujian kepada 32 orang pelajar tingkatan empat. Pengkaji mengambil masa di luar jadual waktu bagi pengajaran dan pembelajaran bahasa Tamil, iaitu dari 2.00 hingga 3.00 petang pada hari Khamis selama 12 minggu juga. Pascaujian juga diadakan di Sekolah B. 
Praujian dan pascaujian dilaksanakan sebelum dan selepas modul diimplementasikan kepada 70 orang pelajar tingkatan empat. Pelaksanaan dua ujian itu adalah bertujuan untuk mengenal pasti tahap pencapaian pelajar-pelajar dalam bidang tatabahasa kata kerja bahasa Tamil sebelum dan selepas menggunakan modul strategi struktur dekonstruktivisme tatabahasa kata kerja bahasa Tamil.

Untuk menganalisis keputusan akademik pelajar-pelajar dalam tatabahasa Bahasa Tamil, ujian-t digunakan. Berikutan itu, hipotesis nul dan alternatif dibangunkan seperti berikut:

1) Hipotesis Nul: Tidak terdapat perbezaan keputusan akademik sebelum dan selepas penggunaan modul tatabahasa kata kerja.

2) Hipotesis Alternatif: Terdapat perbezaan keputusan akademik sebelum dan selepas penggunaan modul Tatabahasa kata kerja.

\section{Dapatan Kajian}

\section{Pembangunan Modul}

Instrumen yang telah dibentuk telah diberi kepada seorang pakar dalam bidang linguistik bahasa Tamil. Instrumen dibuat pembetulan dan pengubahsuaian mengikut pandangan dan cadangan pakar. Setelah pembetulan, soal selidik diserahkan terus kepada 10 orang panel pakar yang telah dipilih.

Kesepakatan panel pakar dari aspek strategi selain strategi dekonstruktivisme, kaedah dan teknik, aktiviti, jenis latihan sumber rujukan dan bahan bantu mengajar dalam mereka bentuk dan membangunkan modul strategi struktur dekonstruktivisme kata kerja tatabahasa bahasa Tamil untuk pelajar tingkatan empat. Dapatan kajian tentang strategi pengajaran dan pembelajaran tatabahasa kata kerja adalah dipaparkan dalam Jadual 2.

\section{Jadual 2}

Strategi Pengajaran dan Pembelajaran Tatabahasa Kata Kerja bagi Pelajar Tingkatan Empat

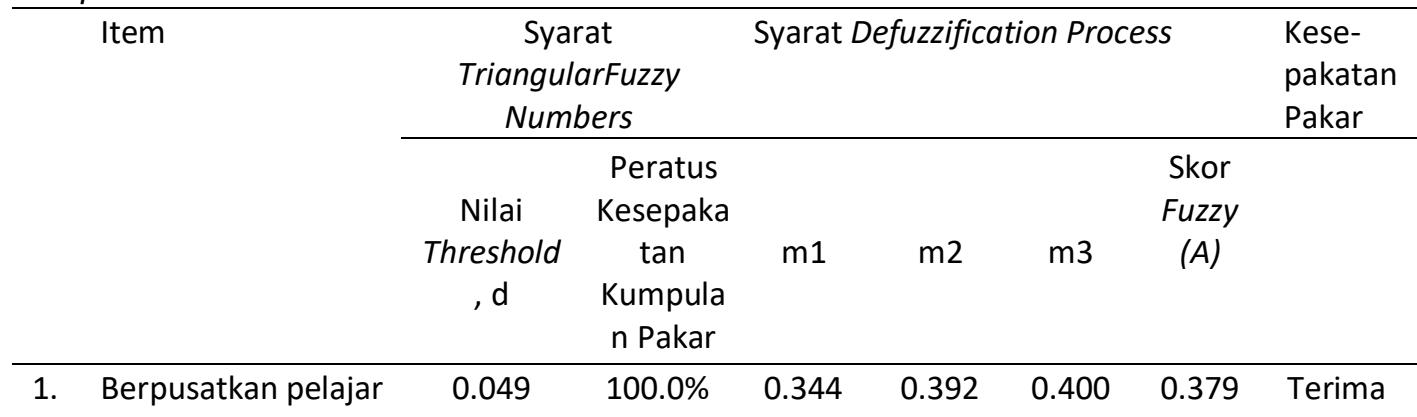




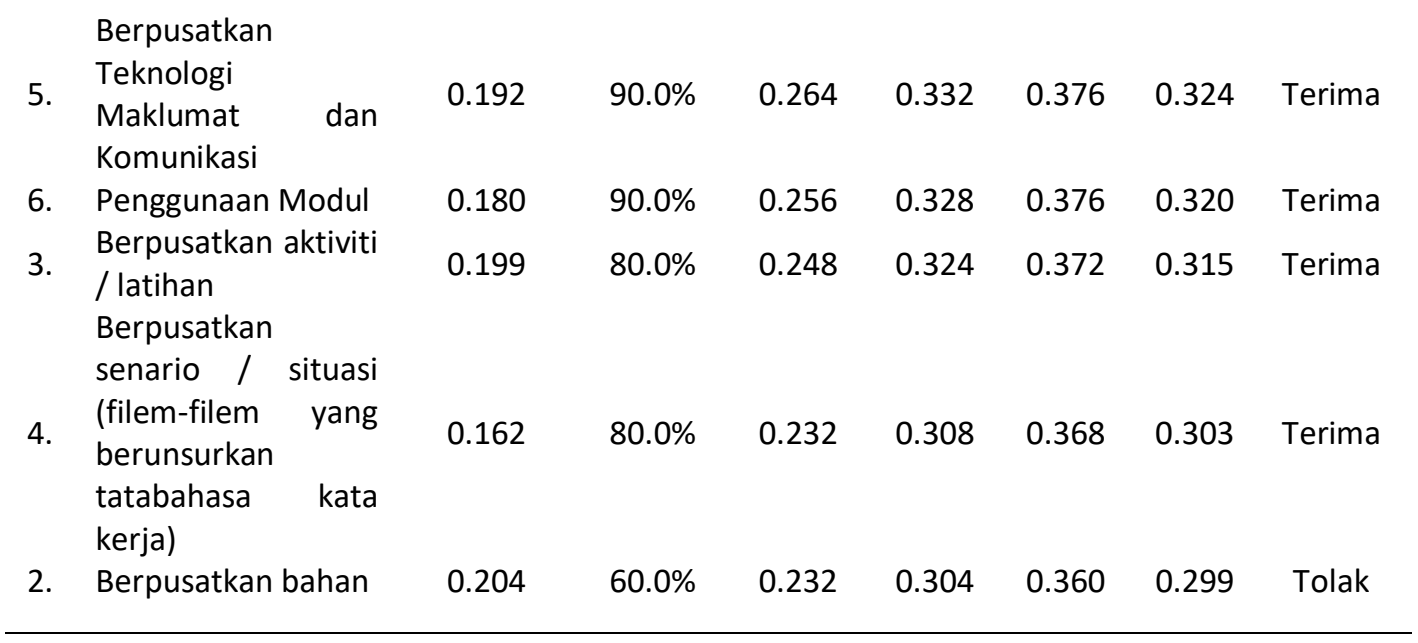

Jadual 2 menunjukkan bahawa strategi pengajaran dan pembelajaran yang berpusatkan pelajar mendapat peratus kesepakatan sepenuhnya (100\%). Ini diikuti dengan strategi berpusatkan teknologi maklumat dan komunikasi dan penggunaan modul mendapat peratus kesepakatan sebanyak $90 \%$. Strategi berpusatkan aktiviti atau latihan dan berpusatkan senario atau situasi pula mendapat peratus kesepakatan sebanyak $80 \%$. Strategi berpusatkan bahan tidak diterima oleh panel pakar kerana tidak mencapai nilai kesepakatan lalu ditolak.

\section{Jadual 3}

Kaedah dan Teknik Pengajaran dan Pembelajaran Tatabahasa Kata Kerja Bahasa Tamil Tingkatan Empat

\begin{tabular}{|c|c|c|c|c|c|c|c|c|}
\hline & \multirow[t]{2}{*}{ Item } & \multicolumn{2}{|c|}{$\begin{array}{c}\text { Syarat Triangular Fuzzy } \\
\text { Numbers }\end{array}$} & \multicolumn{4}{|c|}{ Syarat Defuzzification Process } & \multirow{2}{*}{$\begin{array}{c}\text { Kese- } \\
\text { pakatan } \\
\text { Pakar }\end{array}$} \\
\hline & & $\begin{array}{c}\text { Nilai } \\
\text { Threshold, } \\
\text { d }\end{array}$ & $\begin{array}{l}\text { Peratus } \\
\text { Kese- } \\
\text { pakatan } \\
\text { Kumpulan } \\
\text { Pakar, \% }\end{array}$ & $\mathrm{m} 1$ & $\mathrm{~m} 2$ & m3 & $\begin{array}{l}\text { Skor } \\
\text { Fuzzy } \\
\text { (A) }\end{array}$ & \\
\hline 8. & Induktif & 0.088 & $100.0 \%$ & 0.272 & 0.348 & 0.392 & 0.337 & Terima \\
\hline 9. & Deduktif & 0.065 & $100.0 \%$ & 0.288 & 0.360 & 0.396 & 0.348 & Terima \\
\hline 10. & Integratif & 0.094 & $100.0 \%$ & 0.304 & 0.368 & 0.396 & 0.356 & Terima \\
\hline 11. & $\begin{array}{l}\text { Teknologi } \\
\text { Maklumat }\end{array}$ & 0.088 & $100.0 \%$ & 0.272 & 0.348 & 0.392 & 0.337 & Terima \\
\hline 12. & Latih tubi & 0.155 & $100.0 \%$ & 0.296 & 0.356 & 0.388 & 0.347 & Terima \\
\hline
\end{tabular}

Jadual 3 menunjukkan bahawa kesemua lima item yang ada dalam bahagian ini diterima dengan peratus kesepakatan sebanyak 100\%. Dengan perkataan lain, kaedah 
dan teknik induktif, deduktif, integratif, teknologi maklumat dan latih tubi diterima sepenuhnya oleh panel pakar.

\section{Jadual 4}

Aktiviti Pengajaran dan Pembelajaran Tatabahasa Kata Kerja bagi Pelajar Tingkatan Empat

\begin{tabular}{|c|c|c|c|c|c|c|c|c|}
\hline & \multirow[t]{2}{*}{ Item } & \multicolumn{2}{|c|}{$\begin{array}{c}\text { Syarat Triangular } \\
\text { Fuzzy Numbers }\end{array}$} & \multicolumn{4}{|c|}{ Syarat Defuzzification Process } & \multirow[t]{2}{*}{$\begin{array}{l}\text { Kesepaka } \\
\text { tan Pakar }\end{array}$} \\
\hline & & $\begin{array}{c}\text { Nilai } \\
\text { Threshold, } \\
\text { d }\end{array}$ & $\begin{array}{c}\text { Peratus } \\
\text { Kesepaka } \\
\text { tan } \\
\text { Kumpula } \\
\text { n Pakar }\end{array}$ & m1 & $\mathrm{m} 2$ & $\mathrm{~m} 3$ & $\begin{array}{l}\text { Skor } \\
\text { Fuzzy } \\
\text { (A) }\end{array}$ & \\
\hline 1. & Pembentangan & 0.101 & $100.0 \%$ & 0.312 & 0.372 & 0.396 & 0.360 & Terima \\
\hline 2. & $\begin{array}{l}\text { Permainan } \\
\text { bahasa }\end{array}$ & 0.073 & $100.0 \%$ & 0.328 & 0.384 & 0.400 & 0.371 & Terima \\
\hline 3. & Kolaboratif & 0.076 & $100.0 \%$ & 0.320 & 0.380 & 0.400 & 0.367 & Terima \\
\hline 4. & $\begin{array}{l}\text { Berkongsi } \\
\text { maklumat }\end{array}$ & 0.101 & $100.0 \%$ & 0.312 & 0.372 & 0.396 & 0.360 & Terima \\
\hline 5. & $\begin{array}{l}\text { Menyelesaikan } \\
\text { masalah }\end{array}$ & 0.101 & $100.0 \%$ & 0.312 & 0.372 & 0.396 & 0.360 & Terima \\
\hline 6. & $\begin{array}{l}\text { Membanding } \\
\text { beza }\end{array}$ & 0.128 & $100.0 \%$ & 0.304 & 0.364 & 0.392 & 0.353 & Terima \\
\hline 7. & $\begin{array}{l}\text { Melukis peta } \\
\text { kemahiran } \\
\text { berfikir aras } \\
\text { tinggi (KBAT) }\end{array}$ & 0.076 & $100.0 \%$ & 0.320 & 0.380 & 0.400 & 0.367 & Terima \\
\hline 8. & $\begin{array}{l}\text { Menyatakan } \\
\text { pandangan atau } \\
\text { pendapat }\end{array}$ & 0.094 & $100.0 \%$ & 0.304 & 0.368 & 0.396 & 0.356 & Terima \\
\hline 9. & $\begin{array}{l}\text { Menyatakan } \\
\text { sebab akibat }\end{array}$ & 0.076 & $100.0 \%$ & 0.320 & 0.380 & 0.400 & 0.367 & Terima \\
\hline 11. & $\begin{array}{l}\text { Menyusun } \\
\text { mengikut } \\
\text { urutan }\end{array}$ & 0.128 & $100.0 \%$ & 0.304 & 0.364 & 0.392 & 0.353 & Terima \\
\hline 12. & $\begin{array}{l}\text { Membuat } \\
\text { kategori } \\
\text { klasifikasi }\end{array}$ & 0.101 & $100.0 \%$ & 0.312 & 0.372 & 0.396 & 0.360 & Terima \\
\hline 13. & $\begin{array}{l}\text { Membuat } \\
\text { ulasan }\end{array}$ & 0.132 & $100.0 \%$ & 0.312 & 0.368 & 0.392 & 0.357 & Terima \\
\hline 14. & $\begin{array}{l}\text { Membuat } \\
\text { refleksi }\end{array}$ & 0.076 & $100.0 \%$ & 0.320 & 0.380 & 0.400 & 0.367 & Terima \\
\hline 10. & $\begin{array}{l}\text { Mencari } \\
\text { kesalahan dan }\end{array}$ & 0.087 & $90.00 \%$ & 0.336 & 0.384 & 0.396 & 0.372 & Terima \\
\hline
\end{tabular}


membuat

pembetulan

Jadual 4 menunjukkan bahawa 14 item tentang aktiviti pengajaran dan pembelajaran tatabahasa kata kerja diterima baik oleh panel pakar. Peratus kesepakatan pakar terhadap aktiviti pembentangan, permainan bahasa, kolaboratif, berkongsi maklumat, menyelesaikan masalah, membanding beza, melukis peta Kemahiran Berfikir Aras Tinggi (KBAT), menyatakan pandangan atau pendapat, menyatakan sebab akibat, menyusun mengikut urutan, membuat kategori/klasifikasi, membuat ulasan dan membuat refleksi ialah 100\%, manakala mencari kesalahan dan membuat pembetulan pula mendapat peratus kesepakatan sebanyak 90\%. Ini menunjukkan panel pakar menerima baik kesemua aktiviti tersebut.

\section{Jadual 5}

Latihan Pengajaran dan Pembelajaran Tatabahasa Kata Kerja bagi Pelajar Tingkatan Empat

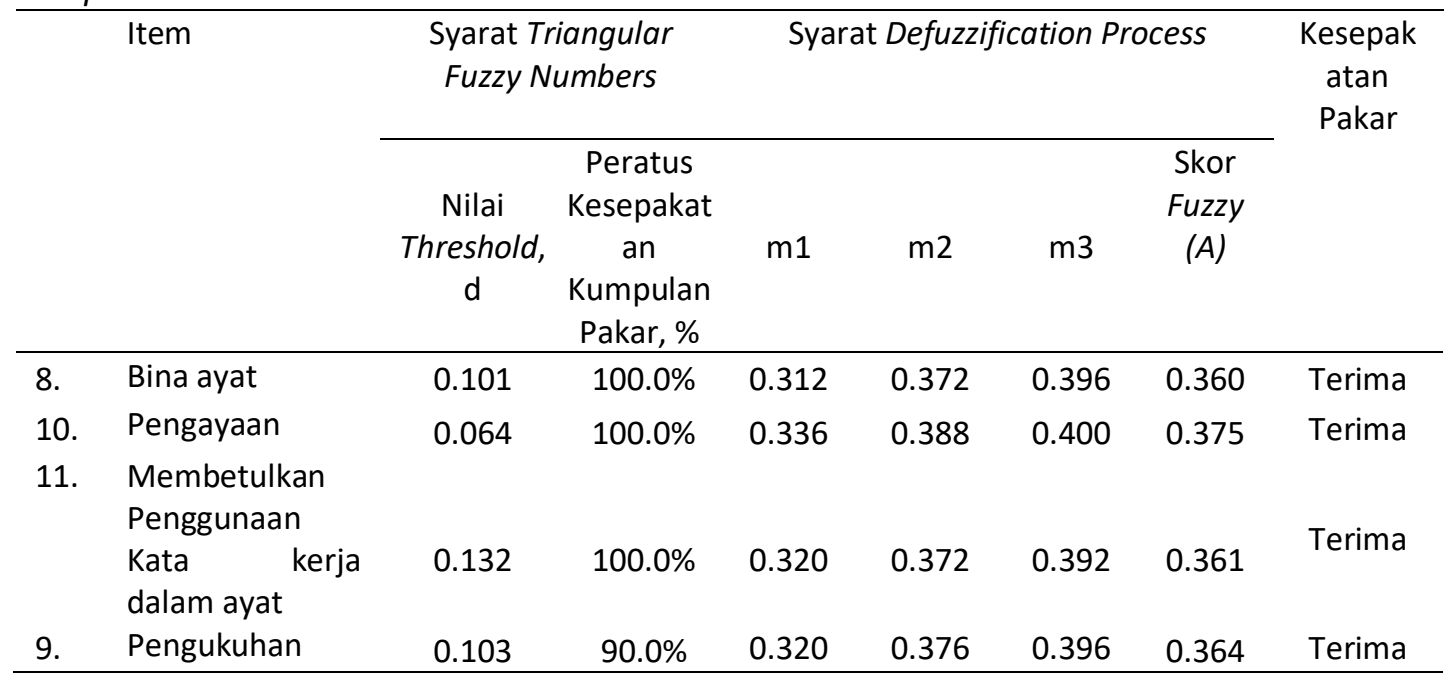

Jadual 5 menunjukkan bahawa empat item mengenai latihan pengajaran dan pembelajaran tatabahasa kata kerja mendapat nilai kesepakatan yang tinggi. Latihan membina ayat, pengayaan dan membetulkan penggunaan kata kerja dalam ayat mendapat peratus kesepakatan sebanyak 100\%, manakala latihan pengukuhan mendapat $90 \%$ persetujuan. Oleh itu, panel pakar menerima kesemua latihan tersebut. 
Jadual 6

Alat Bantu Mengajar yang Sesuai Digunakan

\begin{tabular}{|c|c|c|c|c|c|c|c|c|}
\hline & \multirow[t]{2}{*}{ Item } & \multicolumn{2}{|c|}{$\begin{array}{l}\text { Syarat Triangular Fuzzy } \\
\text { Numbers }\end{array}$} & \multicolumn{4}{|c|}{ Syarat Defuzzification Process } & \multirow{2}{*}{$\begin{array}{l}\text { Kese- } \\
\text { pakatan } \\
\text { Pakar }\end{array}$} \\
\hline & & $\begin{array}{l}\text { Nilai } \\
\text { Threshold, } \\
\text { d }\end{array}$ & $\begin{array}{l}\text { Peratus } \\
\text { Kese- } \\
\text { pakatan } \\
\text { Kumpulan } \\
\text { Pakar, \% }\end{array}$ & $\mathrm{m} 1$ & $\mathrm{~m} 2$ & m3 & $\begin{array}{l}\text { Skor } \\
\text { Fuzzy } \\
\text { (A) }\end{array}$ & \\
\hline 2. & Komputer & 0.076 & $100.0 \%$ & 0.320 & 0.380 & 0.400 & 0.367 & Terima \\
\hline 3. & Papan tulis & 0.145 & $100.0 \%$ & 0.264 & 0.336 & 0.384 & 0.328 & Terima \\
\hline 4. & Internet & 0.073 & $100.0 \%$ & 0.328 & 0.384 & 0.400 & 0.371 & Terima \\
\hline 5. & Lagu & 0.145 & $100.0 \%$ & 0.288 & 0.352 & 0.388 & 0.343 & Terima \\
\hline 6. & Buku teks & 0.185 & $90.0 \%$ & 0.280 & 0.344 & 0.380 & 0.335 & Terima \\
\hline 7. & Projektor & 0.248 & $80.0 \%$ & 0.272 & 0.332 & 0.368 & 0.324 & Terima \\
\hline
\end{tabular}

Jadual 6 menunjukkan bahawa enam item tentang alat bantu mengajar yang sesuai digunakan menerima peratus kesepakatan yang tinggi, iaitu dari $80 \%$ hingga $100 \%$. Komputer, papan tulis, internet dan lagu mendapat peratus kesepakatan sebanyak $100 \%$, manakala buku teks mendapat $90 \%$ dan projektor mendapat $80 \%$ kesepakatan daripada panel pakar. Kesemua item ini diterima baik oleh panel pakar.

Berdasarkan kesepakatan dan persetujuan 10 orang panel pakar melalui teknik Fuzzy Delphi, pengkaji berjaya membangunkan modul strategi dekonstruktivisme tatabahasa kata kerja bahasa Tamil bagi pelajar tingkatan empat. Modul tersebut terdiri daripada enam tajuk utama. Tajuk ini dikenal pasti dari Dokumen Standard Kurikulum dan Pentaksiran (DSKP Semakan) Tingkatan Satu hingga Tingkatan Empat seperti Jadual

Setiap tajuk, iaitu Tajuk 1 hingga Tajuk 6 disusun mengikut proses penulisan langkah demi langkah. Aktivi-aktiviti pula mengikut kesesuaian tajuk atau topik tatabahasa daripada aktiviti yang mudah kepada yang lebih sukar. Penggunaan strategi dekonstruktivisme diajar selepas pelajar mempelajari kata kerja. Ini memudahkan para pelajar untuk mempelajari tatabahasa kata kerja dengan lebih mudah dan teratur.

\section{Jadual 7}

Tajuk-tajuk Modul Strategi Struktur Dekonstruktivisme Tatabahasa Kata Kerja Bahasa Tamil

\begin{tabular}{cl}
\hline Nombor & Tajuk \\
\hline 1 & Pengenalan kata kerja (Vinai chol) \\
2 & Vinai mutru \\
3 & Vinai etcham, ethirmarai vinai \\
4 & Eval vinai, viyangol vinai
\end{tabular}




\section{Kesan Penggunaan Modul}

Untuk tujuan penilaian modul, praujian dan pascaujian dijalankan terhadap 70 orang pelajar tingkatan empat. Hasil analisis ditunjukkan dalam Jadual 8 berikut.

\section{Jadual 8}

Keputusan Ujian-t bagi Praujian dan Pascaujian

\begin{tabular}{lccccc}
\hline Penilaian & $M$ & $S P$ & $T$ & $p$ & $\begin{array}{c}\text { Kesan } \\
\text { Saiz }(\eta)\end{array}$ \\
\hline Praujian & 13.39 & 4.45 & -28.49 & .00 & 3.40 \\
Pascaujian & 26.70 & 3.50 & & & \\
\hline
\end{tabular}

Berdasarkan Jadual 8, keputusan ujian- $t$ adalah signifikan $(t=-28.49, p<.05, \eta=$ 3.40). Hasil kajian menunjukkan terdapat perbezaan pencapaian pelajar tingkatan empat yang signifikan sebelum dan selepas penggunaan modul tatabahasa kata kerja. Nilai skor min yang lebih tinggi selepas penggunaan modul menunjukkan bahawa penggunaan modul dapat membantu meningkatkan tahap pencapaian pelajar dalam tatabahasa kata kerja dengan kesan saiz yang sederhana $(\eta=3.4)$. Oleh itu, hipotesis nul ditolak dan hipotesis alternatif diterima.

\section{Perbincangan}

Berdasarkan konsensus panel pakar yang dicapai melalui teknik Fuzzy Delphi, strategi pengajaran yang perlu dimuatkan ke dalam modul strategi struktur dekonstruktivisme tatabahasa kata kerja bahasa Tamil bagi pelajar tingkatan empat adalah berpusatkan pelajar, teknologi maklumat dan komunikasi, aktiviti/latihan dan senario/situasi (filemfilem yang berunsurkan tatabahasa kata kerja). Semua panel pakar berpendapat sebegitu kerana pelaksanaan kemahiran abad ke-21 dalam pembelajaran bukan sahaja memberi kepentingan kepada para pelajar, malah turut memberi impak yang positif kepada guru-guru, penting untuk guru-guru dan pelajar-pelajar supaya dapat menguasai aktiviti pengajaran dan pembelajaran di dalam kelas dalam keadaaan yang tidak membosankan sebaliknya menyeronokkan (Iberahim et al., 2017).

Di samping itu, penggunaan modul dalam pengajaran dan pembelajaran telah ditekankan sebagai strategi pengajaran yang menarik oleh panel pakar. Ini adalah kerana penggunaan modul amat terhad dalam pembelajaran tatabahasa bahasa Tamil. Kajian yang dilakukan oleh Nik Hassan et al. (2016) menekankan bahawa pihak Kementerian Pendidikan Malaysia (KPM) wajar membekalkan modul mengikut mata 
pelajaran sebagai panduan kepada guru dalam melaksanakan pengajaran dan pembelajaran di dalam bilik darjah kerana penggunaan modul pengajaran dan pembelajaran dapat diselaraskan secara berstruktur di semua sekolah di Malaysia.

Kaedah dan teknik pengajaran dan pembelajaran tatabahasa kata kerja yang sesuai dimuatkan dalam modul strategi struktur dekonstruktivisme tatabahasa kata kerja bahasa Tamil ialah induktif, deduktif, integratif, teknologi maklumat dan latih tubi. Strategi, kaedah atau teknik yang berstrukturkan aspek yang sesuai akan meningkatkan kemahiran pelajar dalam tatabahasa kata kerja di samping melahirkan para pelajar yang seimbang dan harmoni selaras dengan matlamat pendidikan.

Selain itu, aktiviti pengajaran dan pembelajaran yang sesuai dimuatkan dalam modul strategi struktur dekonstruktivisme tatabahasa kata kerja bahasa Tamil ialah pembentangan, permainan bahasa, kolaboratif, berkongsi maklumat menyelesaikan masalah, membanding beza, melukis peta KBAT, menyatakan pandangan atau pendapat, menyatakan pandangan atau pendapat, menyatakan sebab akibat, menyusun mengikut urutan, membuat kategori/klasifikasi, membuat ulasan, membuat refleksi dan mencari kesalahan dan membuat pembetulan. Ini adalah kerana kesemua aktiviti tersebut menekankan pembelajaran abad ke-21 yang diperkayakan dengan pemikiran kreatif, pemikiran inovatif, pemikiran kritis, menitikberatkan penyelesaian serta kecekapan dalam membuat keputusan (Mohd Rusdin \& Ali, 2019). Maka, panel pakar mengharapkan modul tatabahasa kata kerja yang disediakan itu merangkumi aspekaspek pembelajaran abad ke-21. Selain itu, latihan pengajaran dan pembelajaran yang sesuai dimuatkan ke dalam modul strategi struktur dekonstruktivisme tatabahasa kata kerja Bahasa Tamil ialah membina ayat, pengayaan, membetulkan penggunaan kata kerja dalam ayat dan pengukuhan.

Berdasarkan ujian-t terhadap praujian dan pascaujian, terdapat peningkatan pencapaian ketara yang diperolehi sebelum dan selepas pelajar-pelajar belajar dengan berpandukan modul strategi struktur dekonstruktivisme tatabahasa kata kerja bahasa Tamil. Dapatan kajian ini selari dengan kajian yang dilakukan oleh Lai (2017) yang mendapat keputusan penilaian yang sama, iaitu peningkatan dari segi markah karangan bahasa Melayu yang diperoleh sebelum dan selepas pelajar-pelajar menggunakan modul penulisan karangan. Keputusan ini juga selari dengan kajian yang dilakukan oleh Zulkifli et al. (2018) dalam pembangunan modul bahasa Arab yang mendapat sambutan positif dan disokong oleh pensyarah dan pelajar yang menggunakannya.

Pembelajaran aktif dalam kalangan pelajar ditingkatkan dalam penguasaan tatabahasa kata kerja pelajar. Modul strategi struktur dekonstruktivisme juga dapat merangsang kemahiran pelajar, iaitu kemahiran bertutur, mendengar, membaca dan menulis. Segala aktiviti dalam modul ini menekankan keempat-empat kemahiran ini. Pembelajaran yang dipermudahkan dalam tatabahasa kata kerja dapat meningkatkan pemahaman para pelajar. Strategi dekonstruktivisme telah memberi pendedahan yang sangat mendalam bagi pelajar-pelajar yang mempelajari kata kerja. Kata kerja vinai mutru ke vinai etcham dan ethirmarai vinai dan seterusnya mempelajari eval vinai dan viyangol vinai. Pembelajaran kata kerja sempurna hingga kata akar kata kerja telah 
memberi pendedahan yang mendalam bagi memahami tatabahasa kata kerja bahasa Tamil. Ini diikuti dengan aktiviti dan latihan yang menarik minat para pelajar menjadi kekuatan bagi pembelajaran tatabahasa kata kerja.

Di dalam kelas pengajaran tatabahasa, latihan-latihan yang dimuatkan dalam modul pengajaran yang dibangunkan membolehkan pelajar-pelajar menggunakan tatabahasa dengan betul. Aktiviti-aktiviti bahasa yang bermakna membolehkan pelajarpelajar menggunakan struktur bahasa yang dipelajari dengan cara yang berkesan. Hal ini bertepatan dengan Teori Interaksional bahawa proses pemerolehan yang melibatkan proses mental dan interaksional (Thornberry \& Krohn, 2019). Di samping itu, teori interaksionalisme menekankan interaksi linguistik antara guru dengan pelajar supaya mereka dapat mempelajari cara-cara menggambarkan sesuatu dalam bentuk linguistik yang betul dan jelas, seterusnya menguasai makna dan idea dengan lebih tepat (Yahya et al. (2016)) dan ini merangsangkan minat pelajar untuk belajar. Aktiviti-aktiviti bahasa yang bermakna dalam modul binaan membolehkan pelajar-pelajar menggunakan struktur bahasa yang dipelajari dengan cara yang berkesan. Dengan menguasai tatabahasa Bahasa Tamil yang betul, modul tersebut telah membina keyakinan para pelajar untuk berkomunikasi, bertukar idea atau makna yang terkandung dalam modul. Maka Teori Interaksional yang diaplikasikan dalam proses pembangunan modul ini telah membantu dalam membentuk konsep dan teori pembelajaran pelajar-pelajar yang bersesuaian.

Selain itu, pembelajaran kata kerja tatabahasa Bahasa Tamil menggunakan modul berdasarkan teori konstruktivisme merupakan satu proses yang aktif dan reflektif (Brunner, 1966). Strategi pembelajaran konstruktivisme yang aktif membolehkan pengetahuan dibina secara aktif oleh para pelajar (Syahida, 2015; Zainal \& Afrinaleni, 2011), yakni para pelajar membina pengetahuan baharu mereka terhadap tajuk kata kerja tatabahasa Bahasa Tamil yang dipelajari berdasarkan pengetahuan semasa atau pengetahuan lepas serta berkembang secara berterusan. Ini sangat berkait rapat dengan cara maklumat diproses serta tindak balas pelajar terhadap proses $p \& p$ (Ponnuduraj, 2014) yang disampaikan oleh gurunya. Dalam pembelajaran kata kerja tatabahasa, pelajar yang lebih cerdas membantu pelajar lain sewaktu menggunakan dan menjawab aktiviti-aktiviti dalam modul binaan itu. Pada masa yang sama, scaffolding boleh berlaku semasa guru membantu pelajar-pelajar untuk mengenali strategi terbaru dalam mempelajari kata kerja tatabahasa bahasa Tamil.

Sehubungan dengan itu, modul strategi struktur dekonstruktivisme telah membangunkan aktiviti tatabahasa kata kerja Bahasa Tamil yang sesuai untuk para pelajar eksperimen. Hasil kajian ini adalah selari dengan dapatan kajian Hussin dan Marosadee (2019) yang menunjukkan bahawa modul yang dibangunkan berkesan bagi mengatasi masalah miskonsepsi dalam pembelajaran 'adad dan ma'dūd. Pelajar-pelajar belajar penggunaan strategi struktur dekonstruktivisme dalam tatabahasa kata kerja, mengaplikasikan dalam setiap frasa kata kerja, menulis latihan yang berkaitan menggunakan strategi tersebut. Strategi struktur dekonstruktivisme dapat menarik minat pelajar untuk mempelajari, mengaplikasi dan meningkatkan kemahiran dalam 
tatabahasa kata kerja. Selain itu, analisis kritikal dan pemikiran kreatif dapat dibina dengan penggunaan strategi dekonstruktivisme kerana ia mendedahkan andaian metafizik yang tidak dipersoalkan dan percanggahan dalaman dalam bahasa dan sastera (Biesta, 2009).

Justeru itu, pembelajaran strategi struktur dekonstruktivisme tatabahasa kata kerja ini membantu para pelajar untuk menguasai tatabahasa kata kerja dengan lebih mudah. la dapat meningkatkan pelbagai kemahiran, pengetahuan dan seterusnya mengurangkan kesilapan dalam penulisan. Justeru, pembelajaran strategi dekonstruktivisme tatabahasa kata kerja dapat membantu pelajar-pelajar mengasah penguasaan tatabahasa kata kerja mereka yang seterusnya boleh digunakan dalam proses penulisan.

Selain itu, pembelajaran strategi dekonstruktivisme juga meningkatkan pembelajaran kaloboratif yang melibatkan pembelajaran berkumpulan, membantu rakan sebaya dan meningkatkan keyakinan untuk belajar dan menulis. Modul ini mempunyai masa yang mencukupi untuk pengajaran dan pembelajaran semua topik seperti yang dirancangkan. Modul ini juga berkesan dalam pengajaran topik-topik seperti vinai chol, vinai mutru, eval vinai, viyangol vinai, vinai etcham, ethirmarai vinai di samping tan vinai, pira vinai, kunriya vinai dan kunra vinai yang menjadi fokus dalam kajian ini.

\section{Kesimpulan}

Strategi pengajaran dan pembelajaran tatabahasa bahasa Tamil berbentuk konvensional dalam amalan guru di bilik darjah selama ini perlu berubah mengikut perubahan dan perkembangan global. Tatabahasa yang merupakan tunjang perdana dalam Bahasa Tamil perlu diberikan fokus dan suntikan baharu. Oleh yang demikian, modul strategi struktur dekonstruktivisme tatabahasa kata kerja Bahasa Tamil penting untuk dibangunkan. Kajian ini merupakan contoh nyata yang memperlihatkan kepentingan pedagogi dan bahan pembelajaran dengan memenuhi keperluan guru-guru dan pelajarpelajar. Pelajar-pelajar dari pelbagai latar belakang pengetahuan dan pengalaman dalam bidang tatabahasa kata kerja diberikan pendedahan tentang proses strategi struktur dekonstruktivisme dalam mempelajari tatabahasa kata kerja melalui perkembangan isi kandungan dan aktiviti-aktiviti yang mencabar minda, menarik dan sesuai dengan tahap pencapaian pelajar. Hasil kajian ini mendapati modul ini bukan sahaja diterima baik oleh panel pakar, malah dapat meningkatkan penguasaan tatabahasa kata kerja dalam kalangan pelajar tingkatan empat. Kajian ini juga boleh dijadikan sebagai rujukan kepada pihak yang berkepentingan bagi merancang strategi yang mudah dan berkesan untuk pengajaran dan pembelajaran tatabahasa kata kerja yang terkandung dalam KSSM Bahasa Tamil DSKP Semakan bagi tingkatan tiga, empat dan lima. 


\section{Rujukan}

Ali, A., \& Mahamod, Z. (2016). Pembangunan dan kebolehgunaan modul berasaskan bermain bagi pembelajaran kemahiran Bahasa Melayu kanak-kanak prasekolah. Jurnal Pendidikan Bahasa Melayu, 6(1), 16-29.

Ali, N., Abdullah, M. H., \& Ab. Rahman, A. (2019). Keberkesanan modul pembelajaran kendiri strategi pemahaman membaca teks Bahasa Arab (MPK SPMBA) untuk pelajar pengajian Islam di Institusi Pengajian Tinggi. In S. Fahmy, S. H. Syed Omar, N. Abdullah, \& R. M. Mohamed (Eds.), Proceedings of the international conference on islamic civilisation and technology management, Terengganu, 2324 November 2019 (pp. 722-739). Penerbit Universiti Sultan Zainal Abidin.

Aljoundi, E. (2014). Language acquisition theories. University of KwaZulu-Natal Publisher.

Annamala, M. D., Omar, A., \& Veeralakshmi, S. (2017). Penguasaan dan persepsi guru pelatih terhadap pembelajaran tatabahasa Punarchi. Journal of Education and Social Science, 7(1), 141-146.

Biesta, G. (2009). Witnessing deconstruction in education: Why quasa-transcendentalism matters. Journal of Philosophy of Education, 43(3), 391-404. https://doi.org/10.1111/j.1467-9752.2009.00705.x

Gough, N. \& Price, L. (2004). Rewording the World: Poststructuralism, Deconstruction and the 'Real' in Environmental Education. Southern African Journal of Environmental Education, 21, 23-36.

Halliday, M.A.K. (1973). Explorations in the functions of language. London: Edward Arnold.

Halliday, M.A.K. (1975). Learning how to mean: Explorations in the development of language. Edward Arnold.

Halliday, M. A. K. (1978). Language as social semiotic: the social interpretation of language and meaning. Edward Arnold.

Halliday, M. A. K., \& Hasan, R. (1985) Language, context and text: Aspects of language in a social-semiotic perspective. Deakin University Press.

Hussin, M., \& Marosadee, A. H. (2019). Pembinaan modul pembelajaran 'Adad dan Ma 'dūd berpandukan ayat Al-Quran. Issues in Language Studies, 8(1), 86-104. https://doi.org/10.33736/ils.1411.2019

Iberahim, A. R., Mahamod, Z., \& Wan Mohammad, W. M. R. (2017). Pembelajaran abad ke-21 dan pengaruhnya terhadap sikap, motivasi dan pencapaian Bahasa Melayu pelajar sekolah menengah. Jurnal Pendidikan Bahasa Melayu, 7(2), 7788.

Javed, M., Eng, L. S., \& Abdul Rashid, M. (2015). Developing reading comprehension modules to facilitate reading comprehension among Malaysian secondary school ESL students. International Journal of Instruction, 8(2), 139-154. 
Jeyadevi, P. (2020). Pembangunan modul bacaan fonemik bersama warna terhadap kemahiran membaca asas Tamil dalam kalangan murid pemulihan [Unpublished master's thesis]. Universiti Malaya.

Kartheges, P. (2017). Pemikiran kritis dan amalannya dalam masyarakat India berpendidikan Tamil di Malaysia berpandukan teks Tirukkura! [Unpublished doctoral dissertation]. Universiti Malaya.

Kent, L. G., \& Branch, R. M. (2002). Survey of instructional development models (4th ed.). Eric Clearinghouse on Information \& Technology.

Lai, L. C. (2017). Pembangunan dan penilaian modul penulisan karangan Bahasa Melayu tingkatan empat [Unpublished doctoral dissertation]. Universiti Malaya.

Masnan, A. H., Josin, E. H., Zain, A., Zainudin, N. A. S. (2018). Environmental preschool education module based on higher order thinking skills (HOTS). The Turkish Online Journal of Design, Art and Communication (TOJDAC), Special Edition, 1442-1449.

Mohd Rusdin, N., \& Ali, S. R. (2019). Amalan dan cabaran pelaksanaan pembelajaran abad ke-21. In S. Fahmy, S. H. Syed Omar, N. Abdullah, \& R. M. Mohamed (Eds.), Proceedings of the international conference on islamic civilisation and technology management, Terengganu, 23-24 November 2019 (pp. 87-105). Penerbit Universiti Sultan Zainal Abidin.

Muthukumar, P. (2020). Analisis masalah, cara penyelesaian dan pembinaan model dalam penulisan Bahasa Tamil murid Tahun 5 SJK (Tamil) [Unpublished doctoral thesis]. Universiti Pendidikan Sultan Idris.

Nadeson, S. (2011). Penukaran dan pembauran kod dalam kalangan pelajar Tamil sekolah menengah [Unpublished master's thesis]. Universiti Malaya.

Nik Hassan, N. R., Mohd Kosnin, A, \& Zakiah, M. A. (2015, December 20-21). Keperluan modul I-think dalam proses pengajaran dan pembelajaran di sekolah. [Paper presentation]. 2nd International Education Postgraduate Seminar, Universiti Teknologi Malaysia, Johor Bahru, Malaysia.

Rusdi, M. N., Norzan, N., Othman, A. J., Mohd Saad, M. R., Hidayat, R., \& Abu, A. R. (2018). Modul hayati, eksplorasi, berfikir aras tinggi (HEBAT) bacaan: Strategik pengajaran dan pembelajaran membaca. Journal of Research, Policy \& Practice of Teachers \& Teacher Education, 8(2), 71-82. https://doi.org/10.37134/jrpptte.vol8.no2.7.2018

Selvajothi, P. R. (2017). Peralihan dan engekalan Bahasa Tamil dalam kalangan masyarakat Tamil di Kuching, Sarawak [Unpublished doctoral thesis]. Universiti Malaya.

Syahida Nadia Zakaria. (2015). Kesan Pendekatan Konstruktivisme dan Pendekatan Tradisional dalam Pengajaran dan Pembelajaran Komponen Sastera Bahasa Melayu. Jurnal Pendidikan Bahasa Melayu, 5(2), 12-21.

Thornberry, T. P., \& Krohn, M. D. (2019). Interactional theory. In D. P. Farrington, L. Kazemian, \& A. R. Piquero (Eds.), The Oxford handbook of developmental and life course criminology (pp. 248-271). Oxford University Press. 
Vygotsky, L. S. (1978). Mind in society: The development of higher psychological processes. Harvard University Press.

Yahya, N. Y., Mezah, C., \& Mustapha, N. F.M \& Othman, M. S. (2016). Pemilihan kosa kata dalam pembinaan modul pembelajaran asas bahasa Arab untuk pelajar warga emas. Jurnal AL-ANWAR, 2(2), 73-92.

Zainal Abidin Zainuddin \& Afrinaleni Suardi. (2011). Keberkesanan Kaedah Konstruktivisme Dalam Pengajaran dan Pembelajaran Matematik. http://eprints.utm.my/id/eprint/10448/1/Keberkesanan_Kaedah_Konstruktivis me_Dalam_Pengajaran_Dan_Pembelajaran_Matematik.pdf

Zulkifli, M. S., Jamali, H. N., Iksan, H., \& Ismail, A. (2018). Modul pengajaran dan pembelajaran interaktif bahasa Arab di pusat bahasa Arab Selangor (PBAS). Jurnal Sultan Alauddin Sulaiman Shah, 5(1), 128-137. 